\title{
Other Physical Activity
}

National Cancer Institute

\section{Source}

National Cancer Institute. Other Physical Activity. NCI Thesaurus. Code C157006.

A physical activity not elsewhere listed or specified. 